\title{
PREFACE, 1937
}

SAN DIEGO: A California City is one of the publications written by members of the Federal Writers' Project of the Works Progress Administration. Designed primarily to give useful employment to needy unemployed writers and research workers, this project has utilized their experience and abilities in the preparation for the American people of a portrait of America-its history, folklore, scenery, cultural backgrounds, social and economic trends, and racial factors.

Many books and brochures are being written for the American Guide Series. As they appear in increasing numbers we hope the public will come to appreciate more fully not only the unusual scope of this undertaking, but also the devotion shown by the workers-from the humblest field worker to the most accomplished editor engaged in the final critical revision of the manuscript. The Federal Writers' Project, directed by Henry G. Alsberg, is administered by Ellen S. Woodward, Assistant Administrator.

(Signed) HARRY L. HOPKINS

Administrator. 
This page intentionally left blank 